How to Cite: Tazhbayev, Ye.M., Galiyeva, A.R., Zhumagaliyeva, T.S., Burkeyev, M.Zh., Kazhmuratova, A.T., Zhakupbekova, E.Zh., Zhaparova, L.Zh., \& Bakibayev, A.A. Synthesis and characterization of isoniazid immobilized polylactide-co-glycolide nanoparticles. Bulletin of the University of Karaganda - Chemistry, 101(1), 61-70. https://doi.org/10.31489/2021Ch1/61-70

Ye.M. Tazhbayev ${ }^{1}$, A.R. Galiyeva ${ }^{1 *}$, T.S. Zhumagaliyeva ${ }^{1}$, M.Zh. Burkeyev ${ }^{1}$, A.T. Kazhmuratova ${ }^{1}$, E.Zh. Zhakupbekova ${ }^{1}$, L.Zh. Zhaparova $^{1}$, A.A. Bakibayev ${ }^{2}$

${ }^{1}$ Karagandy University of the name of academician E.A. Buketov, Kazakhstan;

${ }^{2}$ Tomsk State University, Russia

(*Corresponding author's e-mail: aldana_karaganda@mail.ru)

\title{
Synthesis and characterization of isoniazid immobilized polylactide-co-glycolide nanoparticles
}

\begin{abstract}
This article considers some aspects of synthesis and characterization of polylactide-co-glycolide nanoparticles immobilized with the antituberculous drug isoniazid. The influence of some synthesis parameters of nanoparticles (the ratio of drug substance: polymer and surfactant concentration) on properties of the obtained nanosomal drug form of isoniazid has been studied. Optimal conditions for obtaining the nanoparticles with the best physicochemical parameters such as: particle size, polydispersity, conversion, etc. have been found. These nanoparticles can be used as drug carriers. The results revealed that a polymer: drug ratio of 1:1 and the use of $3 \%$ Twin 80 are necessary to obtain stable emulsions of nanoparticles of polylactide-co-glycolide with satisfactory characteristics. Average size of the obtained particles was $196.4 \mathrm{~nm}$, and the polydispersity value was 0.323 . The aggregation stability of nanoparticles during 4 hours at temperatures of $4^{\circ} \mathrm{C}$ and $20^{\circ} \mathrm{C}$ has been evaluated. The morphology of the obtained nanoparticles has been studied. Analysis of nanoparticles was characterized by various instrumental methods including gas chromatography and thermogravimetry techniques. The resulting nanoparticles of polylactide-co-glycolide immobilized with isoniazid are stable in time and can prolong the action of the drug. In vitro release of isoniazid from polylactide-co-glycolide nanoparticles has been studied.
\end{abstract}

Keywords: nanoparticles, polylactide-co-glycolide, isoniazid, antituberculousdrug, immobilization, polymers.

\section{Introduction}

Tuberculosis (TB) is one of the top 10 reasons of death worldwide; and the leading cause of death from a single infectious agent (ranking above HIV/AIDS) [1]. Isoniazid (INH) is an important first-line antituberculosis drug (anti-TB) and is used in combination with other anti-TB drugs (Fig. 1, a). The anti-TB drugs are encapsulated in polymer-based nanoparticles (NPs) in order to achieve the best therapeutic effect.

One of the promising polymer carriers is polylactide-co-glycolide (PLGA), which has low toxicity, excellent biological compatibility, and characterized by the absence of inflammation in contact with living organisms (Fig. 1, b). All listed characteristics combined with the controlled mechanical properties, makes PLGA the best polymer for the creation of prolonged systems [2].

PLGA NPs are extremely common in nanosystems, and have been used to encapsulate some anti-TB drugs (Table 1). Examples, such as liposomes/niosomes, polymeric NPs, microspheres composed of different polymers (PLGA, alginate, gelatin and SLNs) have been extensively described in various reviews as reported by Costa et al. 2016 [3].<smiles>NNC(=O)c1ccncc1</smiles>

a) INH<smiles>CC(OC(C)(C)C(=O)COC(C)(C)O)C(=O)C(C)(C)O</smiles>

b) PLGA

Figure 1. Structural formula of isoniazid and polylactide-co-glycolide 
Polymeric NPs of anti-TB drugs

\begin{tabular}{|c|c|c|c|c|c|}
\hline NP & Size & $\operatorname{Drug}(\mathrm{s})$ & $\begin{array}{l}\text { Loading } \\
\text { efficiency }\end{array}$ & Method for producing polymeric NPs & Ref. \\
\hline PLGA & $121-184 \mathrm{~nm}$ & Rifampicin (RIF) & $38 \%-42 \%$ & $\begin{array}{l}\text { Lactose-PLGA-NPs were prepared } \\
\text { by the solvent displacement method }\end{array}$ & [4] \\
\hline PLGA & $186-290 \mathrm{~nm}$ & $\begin{array}{l}\text { RIF, INH, Pyra- } \\
\text { zinamide (PZA) }\end{array}$ & $\begin{array}{l}\text { RIF: } 57 \% \\
\text { INH: } 66 \% \\
\text { PZA: } 68 \%\end{array}$ & $\begin{array}{l}\text { Drug-loaded NPs were prepared } \\
\text { by the multiple emulsion technique }\end{array}$ & {$[5]$} \\
\hline PLGA & $180-400 \mathrm{~nm}$ & RIF, INH, PZA & $\begin{array}{l}\text { RIF: } 54 \% \\
\text { INH: } 64 \% \\
\text { PZA:67\% }\end{array}$ & $\begin{array}{l}\text { Wheat germ agglutinin-coated PLGA-NPs were } \\
\text { prepared by a two-step carbodiimide procedure }\end{array}$ & {$[6]$} \\
\hline PLGA & $200-400 \mathrm{~nm}$ & $\begin{array}{c}\text { RIF, } \\
\text { D-cycloserine }\end{array}$ & N/A & $\begin{array}{c}\text { Drug-loaded NPs were prepared using } \\
\text { a technologically available production method }\end{array}$ & [7] \\
\hline PLGA & $200-250 \mathrm{~nm}$ & RIF & $40-53 \%$ & $\begin{array}{l}\text { NPs were produced by homogenization } \\
\text { under pressure followed by solvent evaporation }\end{array}$ & [8] \\
\hline
\end{tabular}

The entrapment of the therapeutic agents in biodegradable polymeric nano-systems is designed to enhance targeted entry, slow-release, and retention of the antibiotics in the cells for longer periods. It has to not only achieve an improved minimum inhibitory concentration, but also reduce dose frequency. Thus, it supposed to improve patient compliance and reduce systemic side effects associated with conventional free antiTB drugs [9]. In this regard, in order to increase the therapeutic effect of the anti-TB drugINH, we studied the possibility of binding this drug to PLGA NPs.

\section{Experimental}

\section{Preparation of INH loadedPLGA NP}

PLGA (the copolymer of lactide-co-glycolide (50:50), molecular weight 24,000 to 38,000 ) and INH was purchased from Sigma Aldrich. PLGANPs immobilized with INH were prepared using the same method as in [10]. Briefly, INH and PLGA (drug/polymer: 1:1-1:5 by weight), D-mannite (1-5\%), Twin 80 (1-7 \%) and Dimethylsulfoxide (DMSO) are sequentially loaded into a three-necked flask equipped with a stirrer, a backflow condenser and a thermometer at temperatures of 293-298 K. The mixture is stirred and heated up to $323-333 \mathrm{~K}$ for $15-20 \mathrm{~min}$ until the solid phase is completely dissolved; then cooled down to room temperature for $20-30 \mathrm{~min}$. The above-mentioned product is a transparent homogeneous liquid of light yellow color. The resulting suspension volume was regulated to $10 \mathrm{~mL}$, and NPs were washed three times with deionized water and collected by centrifugation at $14000 \mathrm{rpm}$ for $15 \mathrm{~min}$ (Eppendorf, Hamburg, Germany).

\section{Determination of the size of particles, their polydispersity, and morphology}

Particle size and polydispersity of NPs were determined using a dynamic light scattering (DLS) on Malvern Zetasizer Nano S90 (Malvern Instruments Ltd., Malvern, UK). For all measurements, each sample was diluted to the appropriate concentration with deionized water. Each size analysis lasted for $120 \mathrm{~s}$ and was performed at $25^{\circ} \mathrm{C}$ with an angle detection of $90^{\circ}$. The surface morphology of PLGA NPs was analyzed via atomic-force microscope (JSPM-5400 Scanning Probe Microscope «JEOL», Japan).

\section{Encapsulation efficacy (EE\%) within PLGA NPs}

The amount of INH encapsulated within PLGA NPs was determined by measuring the amount of nonencapsulated INH in the aqueous solution recovered after ultracentrifugation and washing of the particles. Encapsulation efficacy was determined by UV spectrophotometer at a wave length of $\lambda_{\max }=262 \mathrm{~nm}$. The EE was calculated using the following formula:

$$
\text { Encapsulation efficiency }(\mathrm{EE} \%)=\frac{\text { Mass of the total Drug }- \text { Mass of free Drug }}{\text { Mass of total Drug }} \times 100 \%
$$

\section{In vitro study of drug release from PLGA NPs}

The in vitro release of INH from PLGA NPs was determined by dialysis in a phosphate-buffered saline (pH 7.4) at $310 \mathrm{~K}$. Liquid samples were placed in a prepared dialysis tube using a pipette. The tube, sealed with clamps, were placed in dialysis vessels with $250 \mathrm{~mL}$ of buffer solution, closed with a lid, and stirred on 
a magnetic stirrer at $200 \mathrm{rpm}$. Dialysate samples $(3 \mathrm{~mL}$ each) were collected periodically. The amount of drug released was recorded on a UV spectrophotometer (Promecolab) at a wavelength of $\lambda_{\max }=262 \mathrm{~nm}$ for the drug, against a pure buffer solution.

\section{Results and Discussion}

The direct introduction of the drug into the reaction medium helps to increase the drug content in the NPs during the synthesizing drug loaded-NPs. However there is a question about the stability of the drug in the reaction, its compatibility with the components of the system, etc. [11]. In order to identify this effect, excerpts were conducted in the presence of the drug and without it. Drug-freePLGA-NPs (empty NPs) were prepared by the same procedure omitting the drug. In reactions with the drug INH was used. PLGA was used as a polymer carrier, and Twin- 80 was used as a stabilizer. Characterization of polymers with and without drug is shown below (Table 2).

Table 2

Characteristics of empty and INH immobilizedPLGANPs

\begin{tabular}{|l|c|c|c|}
\hline \multicolumn{1}{|c|}{ Polymer } & Average particle size, $\mathrm{nm}$ & Polydispersity index & Intensity, \% \\
\hline PLGA NPs & $338.7 \pm 36.4$ & $0.268 \pm 0.02$ & $98.7 \pm 2.25$ \\
\hline PLGA-INH-NPs & $272.2 \pm 26.7$ & $0.431 \pm 0.07$ & $93.1 \pm 1.27$ \\
\hline
\end{tabular}

The lower value of the size of immobilized NPs seems to be related to the compactization of structures caused by the presence of INH.

In continuation of our research, we have made attempts to immobilize the anti-TB drug INH in PLGA NPs and have selected optimal conditions for the synthesis of NPs with satisfactory characteristics. According to the method proposed in Ref. [10], PLGANPs immobilized by INH with the use of different polymer/drug ratio and surfactant concentrations were obtained. The physicochemical characteristics of polymer NPs were determined usingDLS. The investigations results of the effect of PLGA/INH ratio (Table 3, section I) and Twin-80 (Table 3, section II) concentrations on particle size and PDI are given in the Table 3.

Table 3

\section{Physicochemical characteristics of the obtained PLGA-INH-NPs}

\begin{tabular}{|c|c|c|c|c|c|}
\hline $\begin{array}{l}\text { PLGA/INH } \\
\text { ratio }\end{array}$ & $\begin{array}{l}\text { Concentration } \\
\text { of Twin- } 80(\%)\end{array}$ & $\begin{array}{l}\text { Average particle } \\
\text { size }(\mathrm{nm})\end{array}$ & Polydispersity index & Intensity, \% & $\begin{array}{l}\text { Encapsulation } \\
\text { efficiency (\%) }\end{array}$ \\
\hline \multicolumn{6}{|c|}{$\mathrm{I}$} \\
\hline $1: 1$ & 1 & $272.2 \pm 26.7$ & $0.431 \pm 0.07$ & $93.1 \pm 1.27$ & $49.4 \pm 1.91$ \\
\hline $1: 2$ & & $387.3 \pm 56.8$ & $0.420 \pm 0.07$ & $74.7 \pm 17.34$ & $53.5 \pm 0.95$ \\
\hline $2: 1$ & & $341.8 \pm 43.3$ & $0.419 \pm 0.13$ & $94.6 \pm 4.93$ & $62.6 \pm 0.63$ \\
\hline $5: 1$ & & $373.8 \pm 16.6$ & $0.472 \pm 0.07$ & $90.7 \pm 6.91$ & $63.5 \pm 2.72$ \\
\hline \multicolumn{6}{|c|}{ II } \\
\hline \multirow[t]{4}{*}{$1: 1$} & 1 & $272.2 \pm 26.7$ & $0.431 \pm 0.07$ & $93.1 \pm 1.27$ & $49.4 \pm 1.91$ \\
\hline & 1.5 & $248.6 \pm 18.8$ & $0.485 \pm 0.09$ & $94.1 \pm 2.03$ & $64.9 \pm 0.44$ \\
\hline & 3 & $196.4 \pm 19.5$ & $0.323 \pm 0.06$ & $95.6 \pm 2.83$ & $75.7 \pm 3.48$ \\
\hline & 7 & $220.1 \pm 24.3$ & $0.364 \pm 0.08$ & $88.8 \pm 3.80$ & $65.0 \pm 1.66$ \\
\hline
\end{tabular}

It was found that PLGA-INH-NP with satisfactory characteristics are formed at a ratio of polymer/drug $1: 1$ and using $3 \%$ Twin- 80 to obtain stable emulsions. Thus, the average size of the prepared particles was $196.4 \mathrm{~nm}$, the value of polydispersity was 0.323 , and encapsulation efficiency was equal to $75,7 \%$.

For detailed study of morphology of the prepared PLGA NPs immobilized withINH, we took polymer images on a scanning microscope (Fig. 2). 


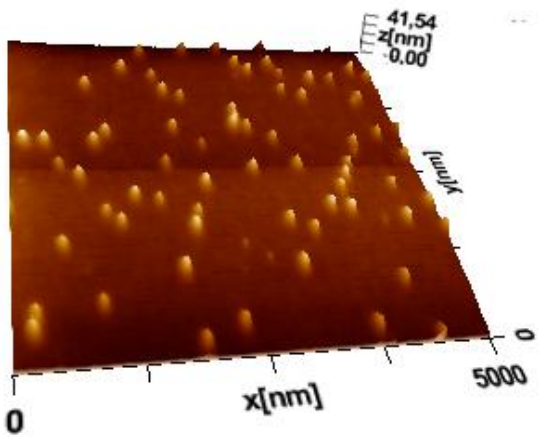

Figure 2. Microphotographs of scanning probe microscopy of PLGA-INH-NPs

All samples prepared for the atomic-force microscope study had a similar topography as presented in Figure 2. The scale at the top right corner of the image is the $\mathrm{Z}$ scale depicting the features that are protruding on the surface. The line scan of the image showed a relatively smooth surface on top of the particle [9]. A small standard deviation was obtained illustrating an overall smooth morphology of the particles. Thus, it is shown that using different ratios of INH and PLGA, as well as Twin 80, NPs of spherical shape with a controlled diameter can be obtained.

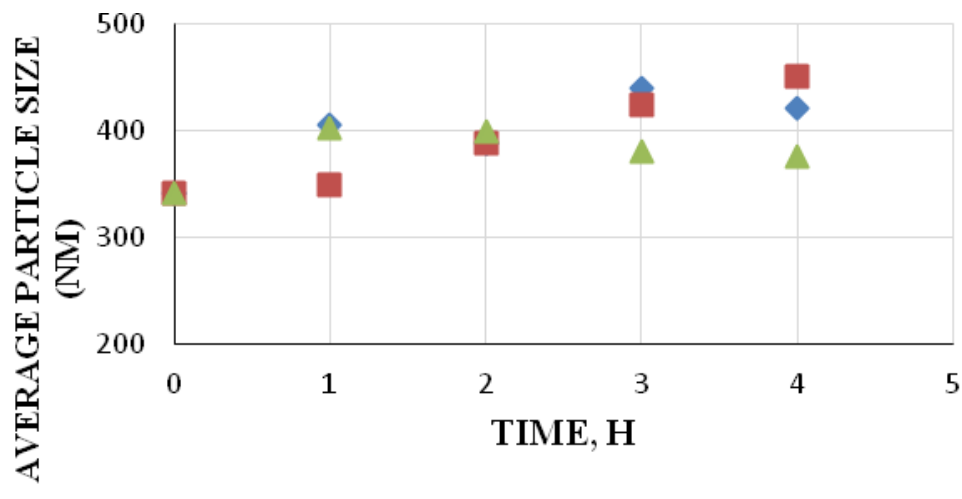

-293K, with stirring $\square 293 \mathrm{~K}$, without stirring $\Delta 277 \mathrm{~K}$, without stirring

$a$

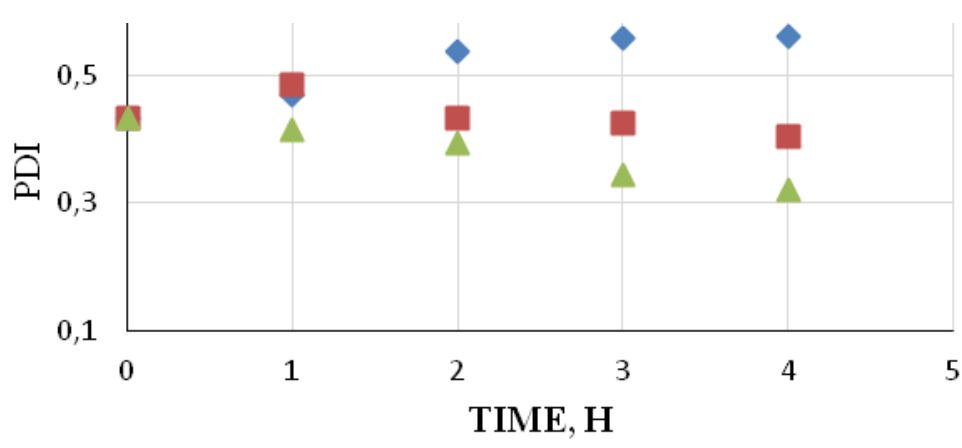

$\bullet 293 \mathrm{~K}$, with stirring $\square 293 \mathrm{~K}$, without stirring $\Delta 277 \mathrm{~K}$, without stirring

$b$

Figure 3. Size $(a)$ and polydispersity index $(b)$ of PLGA-INH-NP within 4 hours

The use of developed PLGANPs in further studies and in practice, suggests that the NPs' suspension must be stable for some time [12]., NPs' aggregation stability therefore was studied during 4 hours at temperatures of $277 \mathrm{~K}$ and $293 \mathrm{~K}$. NPs' sizes in the suspension were determined both with and without stirring, preceding the determination of NPs' sizes. The results presented in Figure 3 demonstrate that in the specified time interval, the particle size practically does not change (as evidenced by both average NPs size and polydispersity index, which should have increased with the appearance of larger fractions and aggregates). 


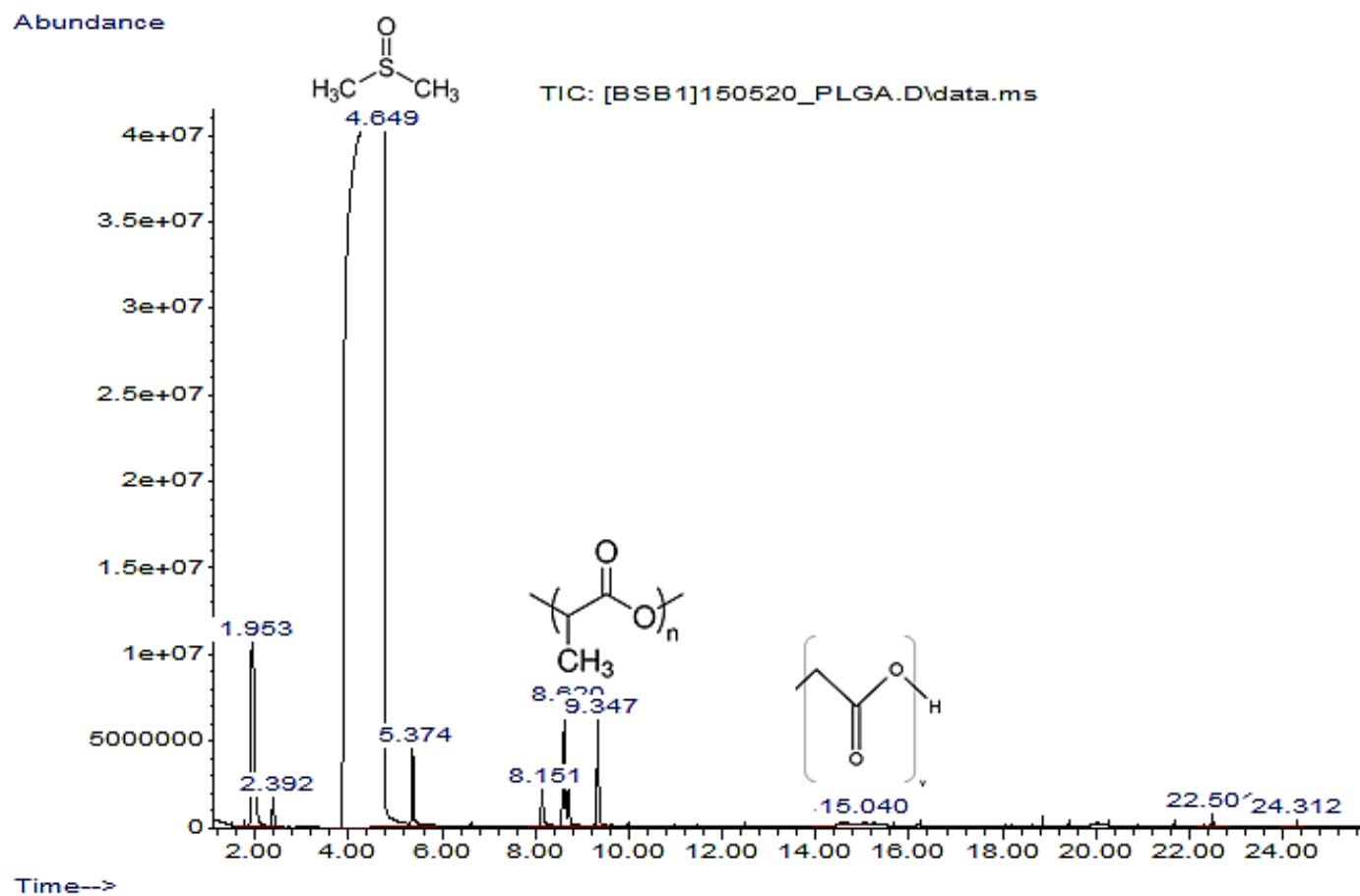

$a$

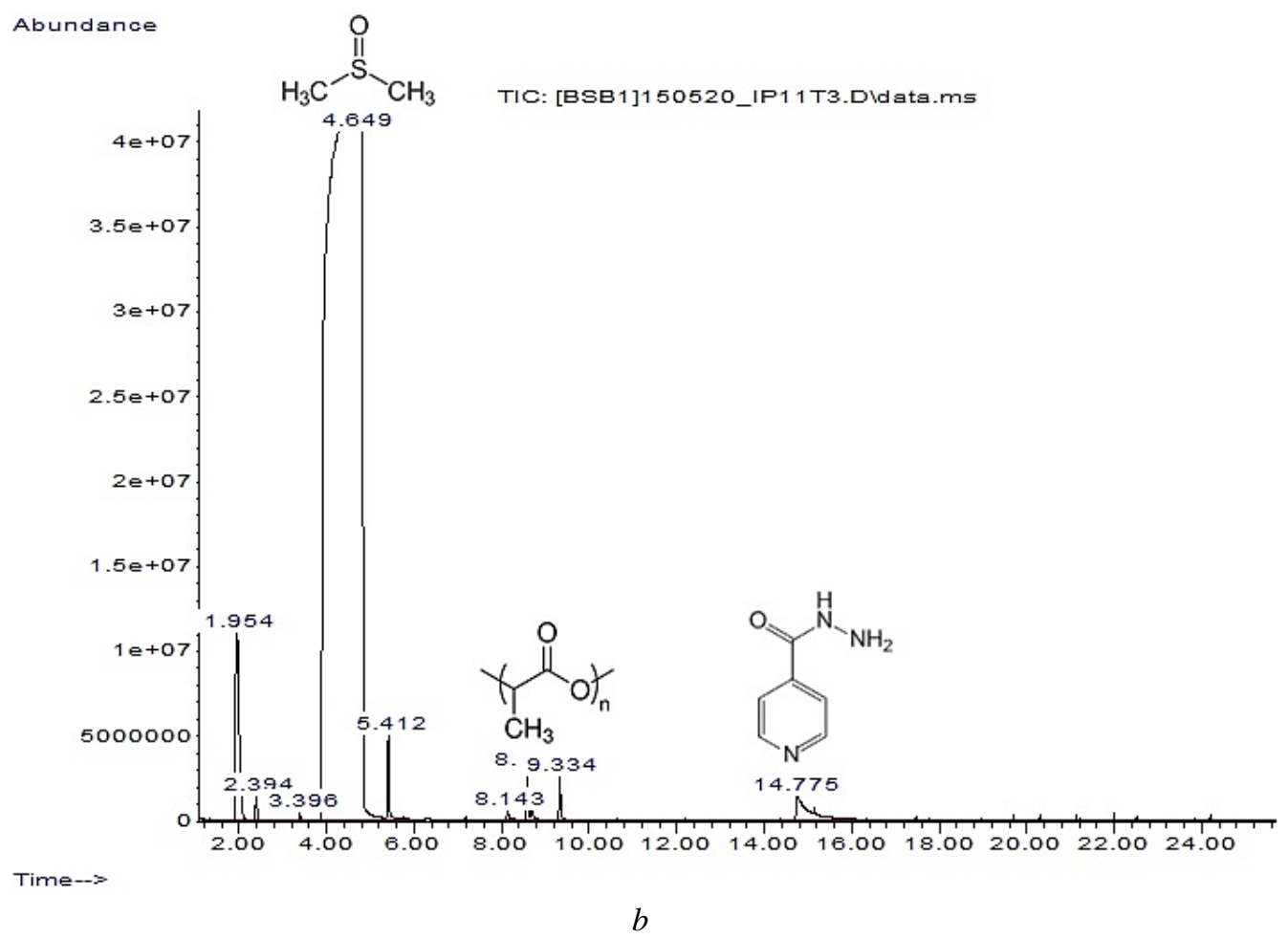

Figure 4. Mass spectra of empty ( $a$ ) and immobilized with INH $(b)$ PLGANPs

Empty and immobilized with anti-TB drugPLGANPs were analyzed by gas chromatography and thermogravimetry techniques. The results of analysis using gas chromatograph with mass-selective detector of the polymer with and without drug are given in Figure 4.

As it can be seen from mass spectra of PLGA NPs, polymers have a wide molecular weight distribution. In both spectra the main compounds are DMSO (94\%), water (2.66\%) and Poly(D-lactide) (0.3-0.78 \%). In addition to the main peaks, one additional peak corresponds to INH $(1,22 \%)$. This suggests that a drug did not change the chemical nature as a result of immobilizing INH in the NPs, this information corroborated with thermogravimetric analysis (TGA) results. 
ISONIAZID

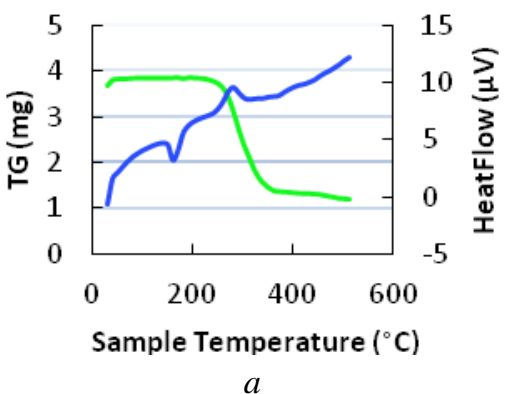

PLGA NPS

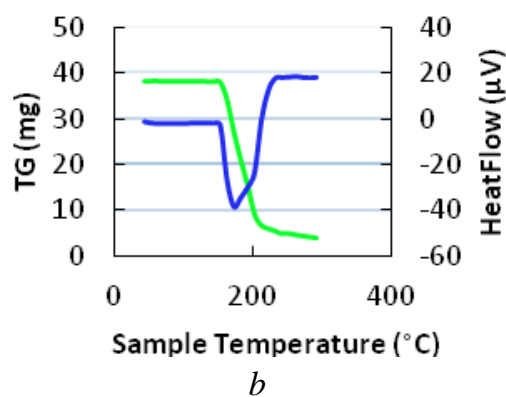

PLGA-INH-NPS

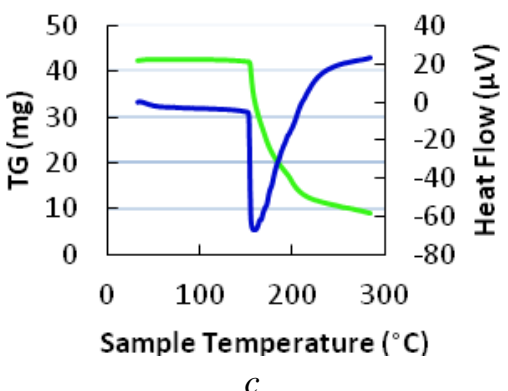

Figure 5. Thermogravimetric curves of INH $(a)$, PLGA-NPs $(b)$ and PLGA-INH-NPs $(c)$

A TGA of the individual system components and the resulting NPs was performed to confirm the inclusion of INH in the complex of PLGA NPs. Figure 5 shows the TGA curves of INH, empty PLGA NPs, and PLGA NPs immobilized with INH. For INH, a characteristic endothermic peak was observed at $162{ }^{\circ} \mathrm{C}$ with enthalpy changes (Fig. $5 a$ ), which was not accompanied by a mass loss and characterized the INH phase transition (a value close to the melting point). Next, an exothermic peak was observed at $282^{\circ} \mathrm{C}$. In the interval of $260-360^{\circ} \mathrm{C}$ there was a mass loss up to $68 \%$, which might correspond to the decomposition temperature of the drug. Empty PLGA NPs showed an endothermic peak at $172{ }^{\circ} \mathrm{C}$ (Fig. 5b), which might correspond to their melting period, with a mass loss of about $90 \%$. On the TGA curve for INH immobilized in the nanoparticle (PLGA-INH-NPs) (Fig. 5c), there was an endothermic peak at $159^{\circ} \mathrm{C}$. The next peak on the TGA curve corresponds to the NPs' decomposition of the polymer at temperature of $150-200{ }^{\circ} \mathrm{C}$ with a mass loss of more than $70 \%$. From the observed curves, it can be concluded that the thermal degradation of PLGA with the drug is slower than the degradation of empty PLGANPs (Fig. 5). The data obtained by physicochemical methods of analysis (gas chromatography and thermogravimetry) allow to conclude that a certain amount of the drug was immobilized in the matrix of PLGA NPs.

When creating polymer-immobilized INH complexes, it is crucial to study the kinetics of drug release from NPs. The release of a drug from nanoparticles has usually been shown to be biphasic, initially by diffusion through the polymer matrix and later by diffusion of the drug and degradation of the polymer matrix itself. PLGA copolymers are degraded in the body by hydrolytic cleavage of the ester linkage to lactic and glycolic acid (Fig. 6). These monomers are easily metabolized in the body via the Krebs cycle and eliminated as carbon dioxide and water [13].

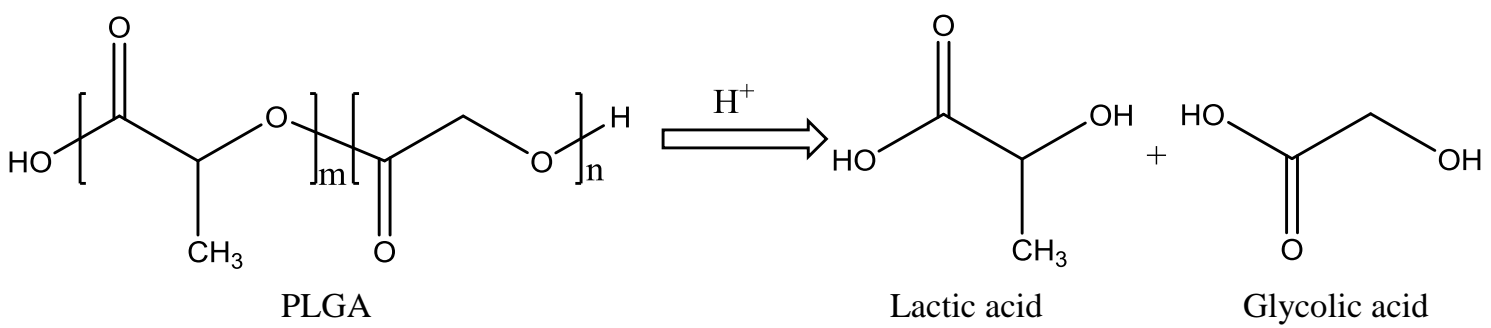

Figure 6. Degradation of polylactide-co-glycolide to lactic and glycolic acid

The principle of the delivery system with controlled drug release is to regulate the kinetics of its release by changing the properties of the polymer matrix. It is also necessary to take into account the kinetic characteristics of the drug. As a result, polymer dosage forms guarantee a constant concentration of the drug in the blood which improves its therapeutic effect. Ideally, the transporting system of drug should ensure its slow absorption by the body tissues. This condition is met by kinetic first order or zero-order release profiles, i.e., extended forms or forms with controlled release can be referred here [14].

The kinetics of drug release from PLGA NPs were studied in phosphate-buffered saline at $\mathrm{pH} 7.4$ for several days by UV-spectrophotometry. Figure 7 shows graphs of drug release obtained by comparing three dosage forms: prolonged release - curve 1, controlled release - curve 2, conventional - curve 3 . 


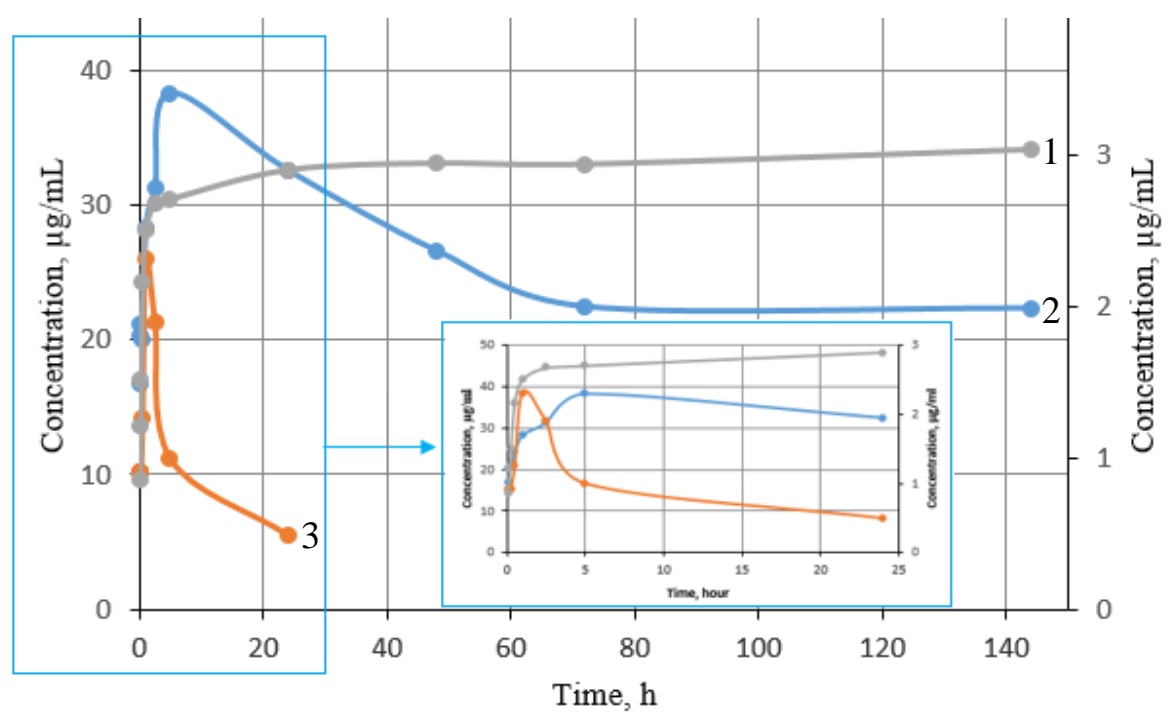

Figure 7. Dependence of INH release rate on time of the samples PLGA-INH-NPs at INH/PLGA ratio: 1:5 (1), 1:1 Twin-80 $3 \%(2)$; and INH (3)

The drug in the conventional dosage form (free INH) provides a single and short-term release of the drug. The drug was released from the dosage form in 5 hours, and the concentration is exponentially reduced until the next dose. Prolonged-release pharmaceutical forms also have a high rate of release in the first 5 hours, although less significant than conventional dosage forms. The drug concentration in blood cannot remain at the same level for long, so it starts decreasing gradually. Drug systems with controlled release eliminate leaps in blood concentration levels of the drug. They maintain a constant therapeutic concentration over a long period of time and result in a stable pharmacological effect [14]. The data presented in Figure 7 show that the release was prolonged for a long time. This property of release kinetics of INH can be used for longterm chemotherapy.

\section{Conclusions}

Thus, the work shows the possibility of including the drug into polymer-carriers directly at the stage of the synthesis of polymeric NPs. The obtained NPs have satisfactory physicochemical characteristics, as evidenced by DLS data. When the obtained NPs were diluted with water, a stable opalescent suspension was formed. The possibility of dilution with water can be used to regulate the dosage of the drug depending on the individual characteristics of the patient. The obtained results should be used for the creation of the drugs with prolonged effect. The data obtained using physicochemical methods of analysis (gas chromatograph and thermogravimetry) reveal that some drugs are immobilized in the matrix of PLGA NPs.

\section{References}

1 Site of World health organization [Electronic resourse]. Access mode: https://www.who.int/tb/publications/global_report/ TB20_Exec_Sum_20201022.pdf

2 Кедик С.А. Полимеры для систем доставки лекарственных веществ пролонгированного действия (обзор). Полимеры и сополимеры молочной и гликолевой кислот / С.А. Кедик, Е.С. Жаворонок, И.П. Седишев, А.В. Панов, В.В. Суслов, Е.А. Петрова и др. // Фармацевтическая технология. — 2013. — № 2 (3). - С. 18-35.

3 Costa A. The formulation of nanomedicines for treating tuberculosis / A. Costa, M. Pinheiro, J. Magalhães // Advanced Drug Delivery Reviews. - 2016. - Vol. 102. - P. 102-115.

4 Jain S.K. Lactose-conjugated PLGA nanoparticles for enhanced delivery of rifampicin to the lung for effective treatment of pulmonary tuberculosis / S.K. Jain, Y. Gupta, L. Ramalingam, A. Jain, A. Jain, P. Khare et al. // Journal of Pharmaceutical Science and Technology. - 2010. - Vol. 64. - P. 278-287.

5 Pandey R. Poly (DL-lactide-co-glycolide) nanoparticle-based inhalable sustained drug delivery system for experimental tuberculosis / R. Pandey, A. Sharma, A. Zahoor, S. Sharma, G.K. Khuller, B. Prasad // Journal of Antimicrobial Chemotherapy. 2003. - Vol. 52. - P. 981-986.

6 Sharma A. Lectin-functionalized poly (lactide-co-glycolide) nanoparticles as oral/aerosolized antitubercular drug carriers for treatment of tuberculosis / A. Sharma, S. Sharma, G.K. Khuller // Journal of Antimicrobial Chemotherapy. — 2004. — Vol. 54. — P. 761-766. 
7 Патент РФ № 2327459. Россия. Лекарственное средство противомикробного действия, способ получения лекарственного препарата направленного действия, содержащего наночастицы / Северин Е.С., Крюков Л.Н., Воронцов Е.А., Кузнецов С.Л., Помазкова Т.А. Опубл. 27.06.2008.

8 Максименко О.О. Влияние технологических параметров на физико-химические свойства полилактидных наночастиц, содержащих рифампицин / О.О. Максименко, Л.В. Ванчугова, Е.В. Шипуло, Г.А. Шандрюк, Г.Н. Бондаренко, С.Э. Гельперина и др. // Хим.-фарм. журн. - 2010. — Т. 44, № 3. - С. $42-47$.

9 Kalombo L. Spray-Dried, Nanoencapsulated, Multi-Drug Anti-Tuberculosis Therapy Aimed at Once Weekly Administration for the Duration of Treatment / L. Kalombo, Y. Lemmer, B. Semete-Makokotlela, B. Ramalapa, T. Nkuna, L. Booysen // Nanomaterials. - 2019. - Vol. 9, No. 1167. - P. 1-14.

10 Патент РФ № 2318513. Россия. Лекарственное средство на основе D-циклосерина, препарат пролонгированного действия, содержащий наночастицы, способ его получения / Северин Е.С., Крюков Л.Н., Зыкова И.Е., Барсегян Г.Г., Воронцов Е.А., Кузнецов С.Л. и др. Опубл. 10.03.2008.

11 Жапарова Л.Ж. Изучение совместимости некоторых противотуберкулезных препаратов с системой радикальной полимеризации / Л.Ж. Жапарова, Е.М. Тажбаев, М.Ж. Буркеев, С.И. Али, А.М. Ван Херк // Вестн. Караганд. ун-та. Сер. Химия. - 2010. — № 4 (60). - С. 36-39.

12 Балабаньян В.Ю. Фармакологические и фармацевтические аспекты создания наноразмерных форм факторов роста нервной ткани феназепама и паклитаксела: дис. ... д-ра фарм. наук: 14.03 .06 — «Фармакология, клиническая фармакология» / Вадим Юрьевич Балабаньян. — М., 2015. — 248 с.

13 Dinarvand R. Polylactide-co-glycolide nanoparticles forcontrolled delivery of anticancer agents / R. Dinarvand, N. Sepehri, S. Manoochehri // International Journal of Nanomedicine. - 2011. — No. 6. - P. 877-895.

14 Филатова Е.В. Лекарственные системы противоопухолевого действия на основе микросфер из поли-3-оксибутирата: дис. ... канд. биол. наук: 03.01.04 - «Биохимия» / Елена Викторовна Филатова. — М., 2019. — 166 с.

Е.М. Тажбаев, А.Р. Галиева, Т.С. Жұмағалиева, М.Ж. Бүркеев, А.Т. Қажмұратова, Э.Ж. Жакупбекова, Л.Ж. Жапарова, А.А. Бакибаев

\title{
Изониазидпен иммобилизацияланған полилактид-со-гликолид нанобөлшектерін синтездеу және зерттеу
}

\begin{abstract}
Туберкулезгеқарсы препарат изониазидпен иммобилизацияланған полилактид-со-гликолид нанобөлшектерін синтездеу және зерттеудің кейбір аспектілері қарастырылған. Нанобөлшектерді синтездеудің кейбір параметрлерінің (дәрілік зат қатынасы : полимер және ББЗ концентрациясы) алынатын изониазидтің наносомалық дәрілік түрінің қасиеттеріне әсері зерттелді. Дәрілік заттарды тасымалдаушы ретінде пайдалану үшін үздік физика-химиялық параметрлері болатын нанобөлшектерді алудың оңтайлы шарттары (бөлшектер мөлшері, полидисперстілігі, конверсия және т.б.) анықталды. Полилактид-со-гликолид нанобөлшектерінің тұрақты эмульсияларын алу үшін полимер / дәрілік қатынасы 1:1 және 3\% Твин-80 қолдану қажет екендігі анықталды. Алынған бөлшектердің орташа мөлшері 196,4 нм, ал полидисперстілік мәні 0,233 құрады. Нанобөлшектердің тұрақтылығы $4^{\circ} \mathrm{C}$ және $20^{\circ} \mathrm{C}$ температурада 4 сағат бойы зерттелді. Алынған нанобөлшектердің морфологиясы зерттелді. Алынған полилактид-со-гликолидтің нанобөлшектері газды хроматография және термогравиметрия әдісімен тексерілген. Изониазидпен иммобилизацияланған полилактид-со-гликолидтің нанобөлшектері уақыт бойынша тұрақты және дәрілік заттың әсерін ұзарта алады. Изониазидтің полилактид-ко-гликолидті нанобөлшектерден in vitro босап шығуы зерттелді.
\end{abstract}

Кілт сөздер: нанобөлшектер, полилактид-со-гликолид, изониазид, иммобилизация, полимерлер.

\author{
Е.М. Тажбаев, А.Р. Галиева, Т.С. Жумагалиева, М.Ж. Буркеев, \\ А.Т. Кажмуратова, Э.Ж. Жакупбекова, Л.Ж. Жапарова, А.А. Бакибаев

\section{Синтез и характеристика наночастиц полилактид-со-гликолида, иммобилизованных изониазидом}

Рассмотрены некоторые аспекты синтеза и характеристики наночастиц полилактид-со-гликолида, иммобилизованных противотуберкулезным препаратом изониазидом. Изучено влияние некоторых параметров синтеза наночастиц (соотношение лекарственное вещество : полимер и концентрация ПАВ) на свойства получаемой наносомальной лекарственной формы изониазида. Найдены оптимальные условия для получения наночастиц с наилучшими физико-химическими показателями (размера частиц, полидисперсности, конверсии и т.д.) для применения в качестве носителей лекарственных препаратов. Установлено, что для получения устойчивых эмульсий наночастиц полилактид-со-гликолида с удовлетворительными характеристиками необходимы соотношение полимер : лекарственное вещество 1:1 и использование $3 \%$ Твин-80. Средний размер полученных частиц составил 196,4 нм, а значение полидисперсности - 0,323. Изучена агрегационная устойчивость наночастиц различного состава в те- 
чение 4-х ч при температурах 4 и $20^{\circ} \mathrm{C}$. Исследована морфология полученных наночастиц. Наночастицы полилактид-со-гликолида изучались методами газовой хроматографии и термогравиметрии. В ходе анализа выявлено, что наночастицы полилактид-со-гликолида, иммобилизованные изониазидом, стабильны во времени и способны пролонгировать действие лекарства. Кроме того, исследовано in vitro высвобождение изониазида из наночастиц полилактид-со-гликолида.

Ключевые слова: наночастицы, полилактид-со-гликолид, изониазид, иммобилизация, полимеры.

\section{References}

1 Site of World health organization. www.who.int Retrieved from https://www.who.int/tb/publications/global_report/ TB20_Exec_Sum_20201022.pdf

2 Kedik, S.A., Zhavoronok, E.S., Sedishev, I.P., Panov, A.B., Suslov, V.V., \& Petrova, E.A. (2013). Polimery dlia dostavki lekarstvennykh veshchestv prolonhirovannoho deistviia (obzor). Polimery i sopolimery molochnoi i hlikolevoi kislot [Polymers for prolonged drug delivery systems (review). Polymers and copolymers of lactic and glycolic acids]. Farmatsevticheskaia tekhnolohiia - Pharmaceutical Technology, 2(3), 18-35 [in Russian].

3 Costa, A., Pinheiro, M., \& Magalhães, J. (2016). The formulation of nanomedicines for treating tuberculosis. Advanced Drug Delivery Reviews, 102, 102-115.

4 Jain, S.K., Gupta, Y., Ramalingam, L., Jain, A., Jain, A., \& Khare, P., et al. (2010). Lactose-conjugated PLGA nanoparticles for enhanced delivery of rifampicin to the lung for effective treatment of pulmonary tuberculosis. Journal of Pharmaceutical Science and Technology, 64, 278-287.

5 Pandey, R., Sharma, A., Zahoor, A., Sharma, S., Khuller, G.K., \& Prasad, B. (2003). Poly (DL-lactide-co-glycolide) nanoparticle-based inhalable sustained drug delivery system for experimental tuberculosis. Journal of Antimicrobial Chemotherapy, 52, 981986.

6 Sharma, A., Sharma, S., \& Khuller, G.K. (2004). Lectin-functionalized poly(lactide-co-glycolide) nanoparticles as oral/aerosolized antitubercular drug carriers for treatment of tuberculosis. Journal of Antimicrobial Chemotherapy, 54, $761-766$.

7 Severin, E.S., Krukov, L.N., Vorontsov, E.A., Kuznetsov, S.L., \& Pomazkova, T.A. (2008). Lekarstvennoe sredstvo protivomikrobnoho deistviia, sposob polucheniia lekarstvennoho preparata napravlennoho deistviia, soderzhashcheho nanochastitsy [Antimicrobial action drug, method of obtaining a targeted Drug containing nanoparticles]. Patent of the Russian Federation No. 2327459. Russia [in Russian].

8 Maksimenko, O.O., Vanchugova, L.V., Shipulo, E.V., Shandryuk, G.A., Bondarenko, G.N., \& Gelperina, S.E. et al. (2010). Vliianie tekhnolohicheskikh parametrov na fiziko-khimicheskie svoistva polilaktidnykh nanochastits, soderzhashchikh rifampitsin [Effect of technological parameters on the physical and chemical properties of polylactide nanoparticles containing rifampicin] Khimiko-farmatsevticheskii zhurnal - Chemico-pharmaceutical Journal, 44, 3, 42-47 [in Russian].

9 Kalombo, L., Lemmer, Y., Semete-Makokotlela, B., Ramalapa, B., Nkuna T., \& Booysen L. (2019). Spray-Dried, Nanoencapsulated, Multi-Drug Anti-Tuberculosis Therapy Aimed at Once Weekly Administration for the Duration of Treatment. Nanomaterials, 9, 1167, 1-14.

10 Severin, E.S., Krukov, L.N., Zykova, I.E., Barsegyan, G.G., Vorontcov, E.A., \& Kuznetcov, S.L., et al. (2008). Lekarstvennoe sredstvo na osnove D-tsikloserina, preparat prolonhirovannoho deistviia, soderzhashchii nanochastitsy, sposob eho polucheniia [Drug based on D-cycloserine, a prolonged-action drug containing nanoparticles, method of its production]. Patent of the Russian Federation № 2318513. Russia [in Russian].

11 Zhaparova, L.Zh., Tazhbaev, E.M., Burkeev, M.Zh., Ali, S.I., \& Van Herck, A.M. (2010). Izuchenie sovmestimosti nekotorykh protivotuberkuleznykh preparatov s sistemoi radikalnoi polimerizatsii [The study of compatibility of some antituberculosis drugs]. Vestnik Karahandinskoho universiteta. Seriia Khimiia - Bulletin of the Karaganda University. Chemistry Series, 4(60), 36-39 [in Russian].

12 Balabanyan, V.Yu. (2015). Farmakolohicheskie i farmatsevticheskie aspekty sozdaniia nanorazmernykh form faktorov rosta nervnoi tkani fenazepama i paklitaksela [Pharmacological and pharmaceutical aspects of the creation of nanoscale forms of neural tissue growth factors phenazepam and paclitaxel]. Doctor's thesis. Moscow [in Russian].

13 Dinarvand, R., Sepehri, N., Manoochehri, S. (2011). Polylactide-co-glycolide nanoparticles forcontrolled delivery of anticancer agents, International Journal of Nanomedicine, 6, 877-895

14 Philatova, E.V. (2019). Lekarstvennye sistemy protivoopukholevoho deistviia na osnove mikrosfer iz poli-3-oksibutirata [Drug systems of antitumor action on the basis of poly-3-oxybutyrate microspheres]. Candidate's thesis. Moscow [in Russian].

\section{Information about authors}

Bakibayev, Abdigali Abdimanapovich - Doctor of Chemical Sciences, Professor, Leading Researcher ofthe Laboratory of Organic Synthesis, National Research Tomsk State University, Lenin str., 36, 634050, Tomsk, Russia; e-mail: bakibaev@ mail.ru; https://orcid.org/0000-0002-3335-3166

Burkeyev, Meyram Zhunusovich - Full Professor, Doctor of Chemical Sciences, Karagandy University of the name of academician E.A. Buketov, Universitetskaya street, 28, 100028, Karaganda, Kazakhstan; e-mail: m_burkeev@mail.ru. https://orcid.org/0000-0001-8084-4825 
Galiyeva, Aldana Rymzhanovna (corresponding author) $-2^{\text {nd }}$ year $\mathrm{PhD}$ student, Department of organic chemistry and polymers, Karagandy University of the name of academician E.A. Buketov, Universitetskaya street, 28, 100028, Karaganda, Kazakhstan.; e-mail: aldana_karaganda@mail.ru; https://orcid.org/0000-0002-8551-6297

Kazhmuratova, Akerke Temirgaliyevna - Candidate of chemical sciences, Assoc. Professor, Karagandy University of the name of academician E.A. Buketov, Universitetskaya street, 28, 100028, Karaganda, Kazakhstan; e-mail: kazhmuratova@ mail.ru; https://orcid.org/0000-0003-4044-8419

Tazhbayev, Yerkeblan Muratovich - Full Professor, Doctor of Chemical Sciences, Karagandy University of the name of academician E.A. Buketov, Universitetskaya street, 28, 100028, Karaganda, Kazakhstan; e-mail: tazhbayev@ mail.ru; https://orcid.org/0000-0003-4828-2521

Zhakupbekova, Elmira Zhumataevna - Candidate of chemical sciences, Assoc. Professor, Karagandy University of the name of academician E.A. Buketov, Universitetskaya street, 28, 100028, Karaganda, Kazakhstan; e-mail: elmira_zhakupbek@mail.ru; https://orcid.org/0000-0003-4384-9859

Zhumagaliyeva, Tolkyn Sergazyevna - Candidate of chemical sciences, Assoc. Professor, Karagandy University of the name of academician E.A. Buketov, Universitetskaya street, 28, 100028, Karaganda, Kazakhstan; e-mail: zhumagalieva79@mail.ru; https://orcid.org/0000-0003-1765-752X

Zhaparova, Lyazzat Zhanybekovna - $\mathrm{PhD}$, Karagandy University of the name of academician E.A. Buketov, Universitetskaya street, 28, 100028, Karaganda, Kazakhstan; e-mail: lyazzh@mail.ru, https://orcid.org/0000-0003-1894-0255 